\title{
LAND USE/COVER CHANGE DETECTION AND VULNERABILITY ASSESSMENT IN INDIGIRKA RIVER BASIN, EASTERN SIBERIA, RUSSIA
}

\author{
M.S. Boori ${ }^{1,2,4}$, K. Choudhary ${ }^{1}$, A.V. Kupriyanov ${ }^{1,3}$, A. Sugimoto ${ }^{4}$, R. Paringer ${ }^{1}$ \\ ${ }^{1}$ Samara National Research University, Samara, Russia \\ ${ }^{2}$ Bonn University, Bonn, Germany \\ ${ }^{3}$ Image Processing Systems Institute - Branch of the Federal Scientific Research Centre "Crys- \\ tallography and Photonics" of Russian Academy of Sciences \\ ${ }^{4}$ Hokkaido University, Sapporo, Japan Abstract
}

\begin{abstract}
Monitoring of land use/cover change is very important for sustainable development planning study. This research work is to understand natural and environmental vulnerability situation and its cause such as intensity, distribution and socio-economic effect in the Indigirka River basin, Eastern Siberia, Russia based on remote sensing and Geographical Information System (GIS) techniques. A model was developed by following thematic layers: land use/cover, vegetation, wetland, geology, geomorphology and soil in ArcGIS 10.2 software using multi-spectral satellite data obtained from Landsat 7 and 8 for the years of 2000, 2008 and 2015 respectively. According to numerical results change detection analysis shows that in first half (2000-2008) Wasteland area was increased from 1015 to $12620 \mathrm{~km}^{2}$ by $15 \%$ and wetland reduced by $13 \%$. In second half from 2008 to 2015 Wasteland shrink more than $13 \%$ and wetland augmented around $9 \%$ but in the same time other classes have minor variation. Resulted vulnerability classified into five levels: low, sensible, moderate, high and extreme vulnerability by mean of cluster principal. The natural vulnerability maximum area covered by moderate $(29.84 \%)$ and sensible $(38.61 \%)$ vulnerability and environmental vulnerability concentrated by moderate $(49.30 \%)$ vulnerability. So study area has at medial level vulnerability. This study is helpful for decision making for eco-environmental recovering and rebuilding as well as predicting the future development.
\end{abstract}

Keywords: Land use/cover, Change detection, Natural and environmental vulnerability, Landsat data, Remote Sensing, GIS.

Citation: Boori MS, Choudhary K, Kupriyanov AV, Sugimoto A, Paringer R. Land use/cover change detection and vulnerability assessment in Indigirka river basin, eastern Siberia, Russia. CEUR Workshop Proceedings, 2016; 1638: 270283. DOI: 10.18287/1613-0073-2016-1638-270-283 


\section{Introduction}

Russia has a largely continental climate because of its sheer size and compact configuration. Most of its land is more than 400 kilometers $(250 \mathrm{mi})$ from the sea and the centre is 3,840 kilometers $(2,386 \mathrm{mi})$ from the sea. In addition, Russia's mountain ranges, predominantly to the south and the east, block moderating temperatures from the Indian and Pacific Oceans but European Russian and northern Siberia lack such topographic protection from the Arctic and North Atlantic Oceans. Indigirka River basin located in Eastern Siberia, Russia with the mouth in Artic Sea. It's the area of high environmental sensitivity zone due to harsh climatic conditions with maximum time frozen temperature below then zero. The climate of Eastern Siberia is mostly continental, mean large temperature difference in summer and winter. The winter is extreme cold and long and summer is warm and small. Although there is relatively little precipitation in eastern Siberia and the winter frost penetrates quite deep, the climate becomes milder and warmer towards the west and south. Due to heavy rainfall, the region is drained by numerous rivers and dotted with lakes filled with a variety of fish [1-2]. Eastern Siberia is rich in timber, diamonds, gold, coal, fur, copper and tin and has deposits of petroleum, natural gas and uranium. Perhaps because of its vastness, richness and relative emptiness, Eastern Siberia seems to inspire human activity on a phenomenal scale [3]. From the world's longest oil pipeline, to the largest diamond mine, to the second longest railway tunnel, the region has long been the target of big dreams and ambitious plans - and yet remains, as it was, vast and relatively empty is the main cause to study land use/cover change and natural and environmental vulnerability of the Eastern Siberia [4].

Presently remote sensing and GIS techniques are the powerful tool to investigate, predict and forecast environmental change scenario in a reliable, repetitive, noninvasive, rapid and cost effective way with considerable decision making strategies [5-6]. This research work uses a new approach by integrating the above mention potential impacts for vulnerability assessment. Analysis can help to solve the multidisciplinary problems such as most or least vulnerable regions, their comparing, in unassessable and harsh climatic conditions. In this research work we use geology, geomorphology, soil, wetland, vegetation and land use scenarios for vulnerability assessment [7]. In this context, the main aim of this study is: (1) build a model of spatial distribution of natural and environmental vulnerability through remote sensing and GIS; (2) knowing the parameters used to obtain clarity of vulnerability; (3) knowing the level of vulnerability in different parts of the study area [8].

\section{Study area}

The study area is located in the Indigirka River basin, eastern Siberia. The geographic coordinates are in between $68^{\circ} 58^{\prime} 01^{\prime \prime}$ to $72^{\circ} 43^{\prime} 40^{\prime \prime} \mathrm{N}$ latitude and $147^{\circ} 18^{\prime} 12^{\prime \prime}$ to $153^{\circ} 24^{\prime} 20^{\prime \prime}$ E longitude (Fig. 1). The region occupies an area of $74610.95 \mathrm{~km}^{2}$. The average annual temperature is below freezing. Annual precipitation ranges from 400 
to $600 \mathrm{~mm}$ in the western part, gradually decreasing to $200 \mathrm{~mm}$ eastward in the average summer (June, July, August) and the differences in the other meteorological values, such as solar radiation were negligibly small (Baseline Meteorological Data in Siberia (BMDS) Version 5.0, [9]. Chokurdakh is the biggest town in the study area with 2367 inhabitants. The territory of Siberia extends eastwards from the Ural Mountains to the watershed between the Pacific and Arctic drainage basins. Siberia stretches southwards from the Arctic Ocean to the hills of north-central Kazakisthan and to the national borders of Mongoliya and China. Siberia accounts for $77 \%$ of Russia`s land area but it is home to just 40 million people $-27 \%$ of the country`s population. This is equivalent to an average population density of about 3 inhabitants per square kilometre (approximately equal to that of Australia), making Siberia one of the most sparsely populated region on Earth [10].

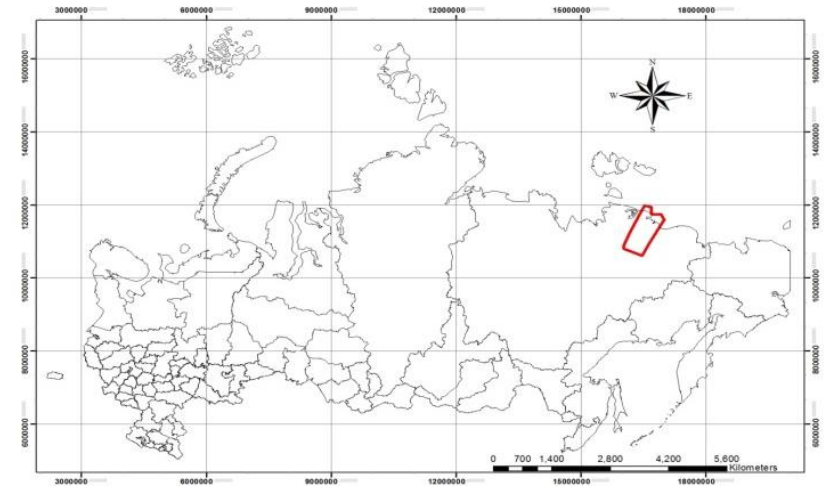

Fig. 1. Location map of the study area.

\section{Data and methodology}

\section{Data}

In this research work we used primary (satellite data) and secondary data such as ground truth for land use/cover classes and topographic sheets. The ground truth data were collected using Global Positioning System (GPS) for the year of 2008 and 2015 in the month of June to August for image analysis and classification accuracy. A selection of multi-sensor, multi-resolution and multi-temporal images was used in this study. The specific satellite images used were Landsat ETM+ (Enhanced Thematic Mapper plus) for 2000 and 2008, Landsat OLI (Operational Land Imager) for 2015, an image captured by a different type of sensor [11].

\section{Image pre-processing and classification}

In pre-processing, first all three images were georeferenced by WGS 1984 UTM projection, later on calibrated and remove there errors/dropouts. We use specific band combination and use image enhancement techniques such as histogram equalization 
to improve the classification accuracy. At this stage, 60 points were selected as GCPs (Ground Control Points) for all images. Data sources used for the GCP selection were: digital topographic maps, GPS (Global Positioning System) acquisitions. The data of ground truth were adapted for each single classifier produced by its spectral signatures for producing series of classification maps. For land use/cover classification, supervised maximum likelihood algorithm (MLC) was used in ArcGIS 10.2 software. MLC classification is based on training sites (signature) provided by the analyzer based on his/her experience or knowledge [12]. After training site whole image classified according to similar digital value of training site and finally classification give land use/cover classified image of the area. Five main land cover classes have been find namely settlements, vegetation, water/ice wetland and wasteland in the study area (table. 1).

Table 1. Classes delineated on the basis of supervised classification.

\begin{tabular}{|c|c|c|}
\hline $\begin{array}{l}\text { Sr. } \\
\text { No. }\end{array}$ & Class name & Description \\
\hline 1 & Settlements & $\begin{array}{l}\text { Residential, commercial, industrial, transportation, roads, } \\
\text { mixed urban }\end{array}$ \\
\hline 2 & Vegetation & Mixed forest, crop field, plantation, grass \\
\hline 3 & Water/Ice & $\begin{array}{l}\text { Permanent or temporary water body, Indigirka river and its } \\
\text { mouth to the Arctic sea in frozen and unfrozen condition }\end{array}$ \\
\hline 4 & Wasteland & Unfertile and rocky land, not useful for agriculture \\
\hline 5 & Wetland & $\begin{array}{l}\text { Land whose soil is saturated with full of moisture either } \\
\text { permanently or seasonally, so such areas are covered either } \\
\text { partially or completely by shallow pools of water. }\end{array}$ \\
\hline
\end{tabular}

\section{Image Land use/cover change detection}

Change detection describes changes in the two satellite image for the same area in two different dates. In this research work three date data (2000, 2008 and 2015) were used to identify the changes in the study area. Following the classification of imagery from each individual year, a multi-date, post-classification comparison, changedetection algorithm was used to determine changes during two intervals for 20002008 and 2008-2015. The post-classification approach provides "from-to" change information which facilitates easy calculation and mapping of the kinds of landscape transformations that have occurred, as shown in Figure (fig. 2). Classified image pairs of two different decade data were compared using cross-tabulation in order to determine qualitative and quantitative aspects of the changes for the periods of 2000 to 2015 , then charts the spatial breakdown of all the land-cover classes that are used in Figure 2.

\section{Data analysis}

All multi-spectral and temporal data were georeferenced based on topographic sheets with the help of ArcGIS 10.2 software. To improve the quality of research analysis 
we used different band ratio, image enhancement techniques, principal component analysis and in last supervised classification.

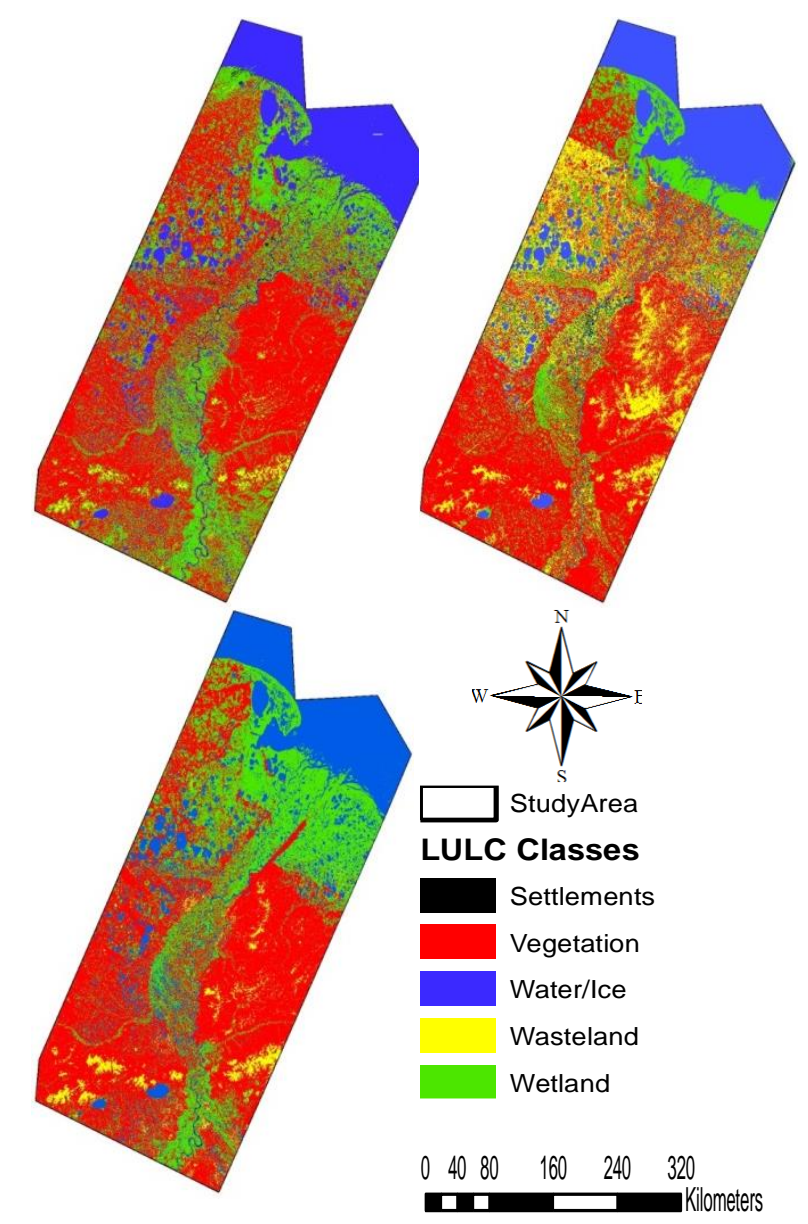

Fig. 2. Land use/cover status of the eastern Siberia; (a) in 2000, (b) in 2008 and (c) 2015 (based on Landsat ETM+ and OLI Satellite Imagery).

Table 2. Stability values of landscape units [3].

\begin{tabular}{ccc}
\hline Unit & $\begin{array}{c}\text { Pedogenesis / } \\
\text { morphogenesis Relation }\end{array}$ & Value \\
\hline Stable & $\begin{array}{c}\text { Prevails pathogenesis } \\
\text { Intermediate }\end{array}$ & $\begin{array}{c}\text { Balance between pedogen- } \\
\text { esis and morphogenesis }\end{array}$ \\
Unstable & Prevails morphogenesis & 1.0 \\
\hline
\end{tabular}


Table 3. Weight table to each unite in a thematic layer.

\begin{tabular}{|c|c|}
\hline Thematic maps/classes & Vulnerability grade levels \\
\hline \multicolumn{2}{|l|}{ Land use/cover } \\
\hline Settlements & 3 \\
\hline Vegetation & 1.5 \\
\hline Water/Ice & 0.5 \\
\hline Wasteland & 1 \\
\hline Wetland & 2 \\
\hline \multicolumn{2}{|l|}{ Vegetation } \\
\hline Alluvial & 3 \\
\hline Forest with open woodland & 1.8 \\
\hline Swamps & 2.5 \\
\hline Tundra & 2 \\
\hline \multicolumn{2}{|l|}{ Wetland } \\
\hline Swamps with Forests $(10-30 \mathrm{~cm})$ & 2 \\
\hline Swamps with Grass, forest \& Shrubs (<30cm) & 1.5 \\
\hline Swamps with Grasses \& Shrubs $(10-30 \mathrm{~cm})$ & 3 \\
\hline Swamps with Shallow Peat $(30-50 \mathrm{~cm})$ & 2.5 \\
\hline \multicolumn{2}{|l|}{ Geomorphology } \\
\hline Costal trays & 2 \\
\hline Pond & 1 \\
\hline River planes & 2.5 \\
\hline Sea/River & 0.5 \\
\hline Urban & 3 \\
\hline Hilly terrain & 1.5 \\
\hline \multicolumn{2}{|l|}{ Geology } \\
\hline Alluvial & 2.5 \\
\hline $\begin{array}{l}\text { Deluvial-coluvial and creep deposits (without } \\
\text { subdivision) }\end{array}$ & 2 \\
\hline Eluvium and deluvium of massive rocks & 2.5 \\
\hline Limnetic deposits & 3 \\
\hline Solifluction and diluvium-creep & 1.5 \\
\hline \multicolumn{2}{|l|}{ 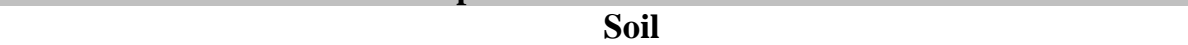 } \\
\hline Gleysems peaty and peaty-humic tundra & 2 \\
\hline Gleyzems and weak-gley humic tundra & 2.5 \\
\hline $\begin{array}{l}\text { Gleyzems differentiated peaty-humic and peat } \\
\text { tundra }\end{array}$ & 2 \\
\hline Gleyzems peaty and peat boggy & 2.8 \\
\hline Gleyzems shallow and deep peat tundra & 3 \\
\hline Podburs tundra ( without subdivision) & 1 \\
\hline Taiga peaty-muck high-humic non-gleyic & 1.5 \\
\hline Sea/River water & 0.5 \\
\hline
\end{tabular}






Wetland

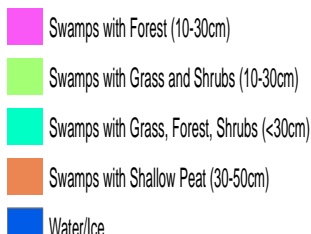

Vegetation
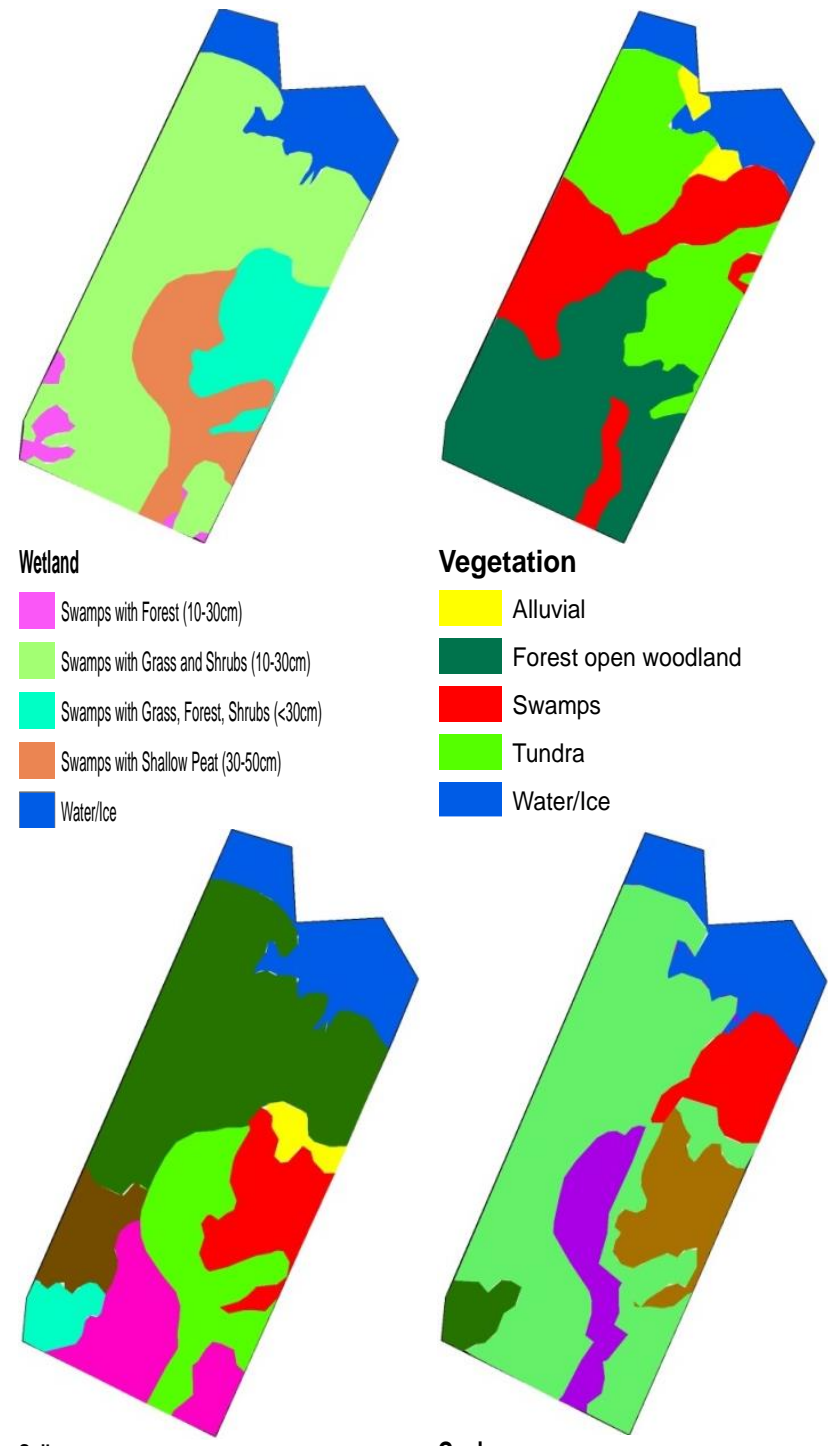

Soil
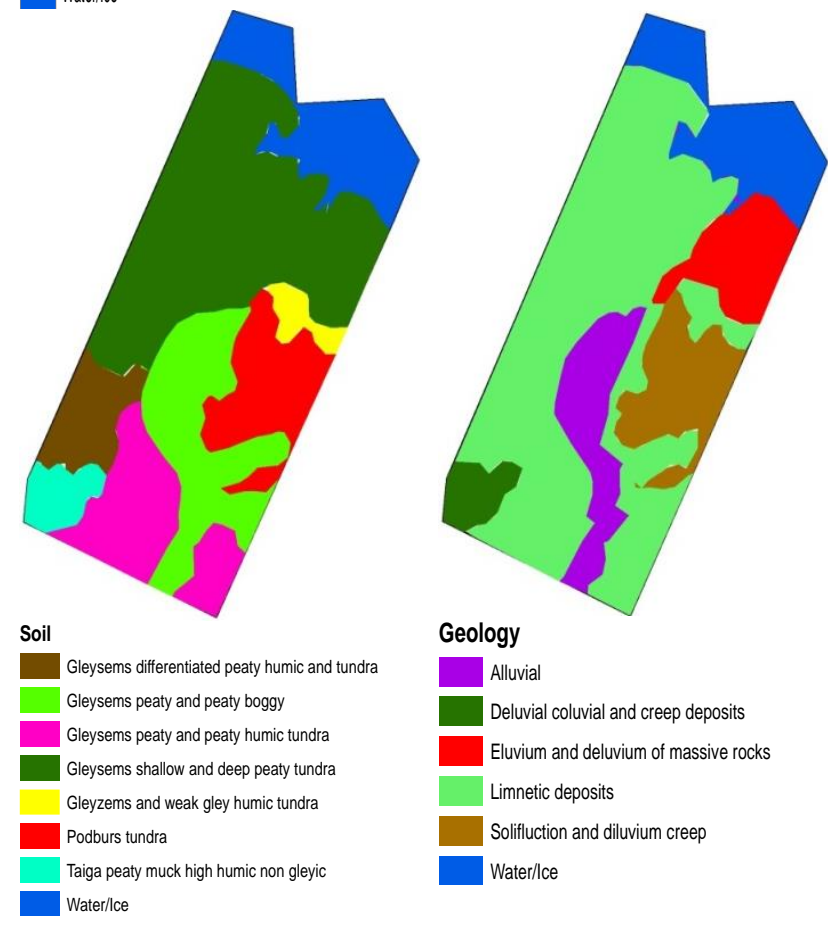

Geology

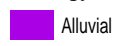

Deluvial coluvial and creep deposits

Eluvium and deluvium of massive rocks

Limnetic deposits

Solifluction and diluvium creep

Water/lce 

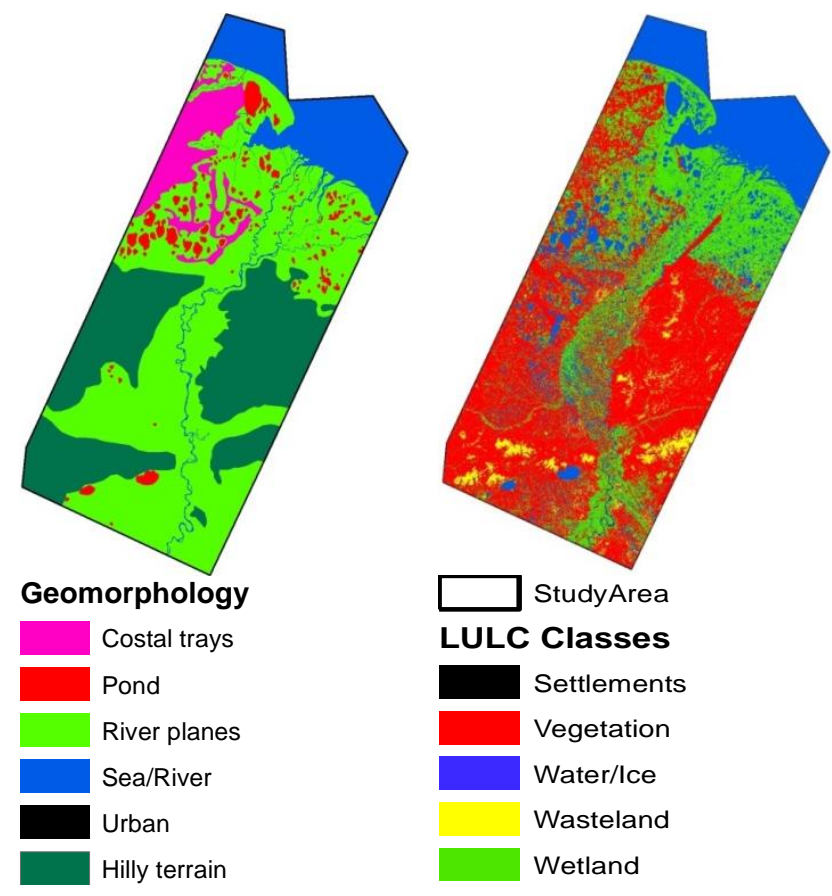

Fig. 3. Simplified wetland, vegetation, soil, geology, geomorphology and land use/cover map.

Thematic maps (fig. 3) of geology, geomorphology, soil, wetland, vegetation and land use/cover were prepared from Landsat ETM+ and OLI imageries. The weight of all landscape units based on $[3,11]$ stability concept, where stability was classified according to table 2 . The weights of a landscape unit indicate the importance of any factor in relation to others [13]. In natural vulnerability all thematic layer give same weight but in environmental vulnerability all thematic layer were given different weight based on their sensitivity or effectiveness in the study area [14].The degree of vulnerability for all units was range from 0.0 to 3.0 (table 3 ) based on [11]. The degree of vulnerability varies from 0 to 3 and is ranked as extreme, high, moderate, sensible and low vulnerability. The weights of compensation indicate the importance of any factor in relation to others, as can be seen in the formula below for natural vulnerability map.

$[($ Theme 1$)+($ Theme 2$)+($ Theme 3$)+($ Theme 4$)+($ Theme 5$)] / 5$

For environmental vulnerability:

$0.2 \mathrm{X}[$ Theme 1] + 0.1X [Theme 2] + 0.1 X [Theme 3] + 0.1X [Theme 4] + 0.1X [Theme 5] + 0.5X [Theme 6]

Where: Theme 1: Geomorphology map, Theme 2: Simplified geological map, Theme 3: Soil/soil system map, Theme 4: Vegetation/biodiversity map, Theme 5: Wetland map and Theme 6: Land use/cover map.

The result mean was distributed in following five natural and environmental vulnerability classes: Low vulnerability: less than or equal to 1.00; Sensible vulnerability: 1.1 to 1.50; Moderate vulnerability: 1.51 to 2.00; High vulnerability: 2.1 to 2.50 and Extreme vulnerability: greater than or equal to 2.51 . 


\section{Results}

\section{Land use/cover status}

Figure 2 shows land use/cover image after supervised classification. These images provide pattern of land use/cover of the study area. The black color represent settlements, red color vegetation, blue color water/ice, yellow color shows the Wasteland and green color shows wetland. All land cover class maps were compared with reference data, which was prepared by ground truth, sample points and google earth. Over all classification accuracy of the study area was more than $90 \%$ for all three dates.

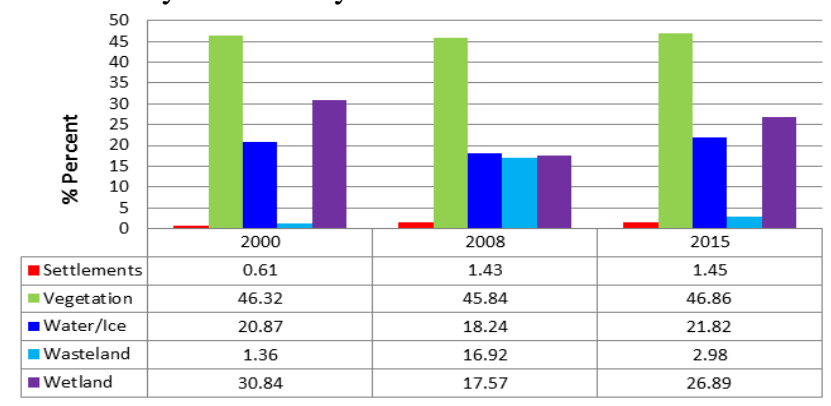

Fig. 4. Land use/cover for eastern Siberia in 2000, 2008 and 2015.

Results shows that vegetation has been most dominant class in the study are for all three dates (fig. 4). Settlements of the study are was less than 2 percent of the total study due to extreme cold and severe climatic conditions. Since 2000 to 2015 water/ice and wetland were little bit variate but Wasteland was increase very high in 2008 due to extreme ice and cold situation in the 2008 (fig. 4). These land use/cover change variables from 2000 to 2015 were mainly caused by natural and climatic conditions

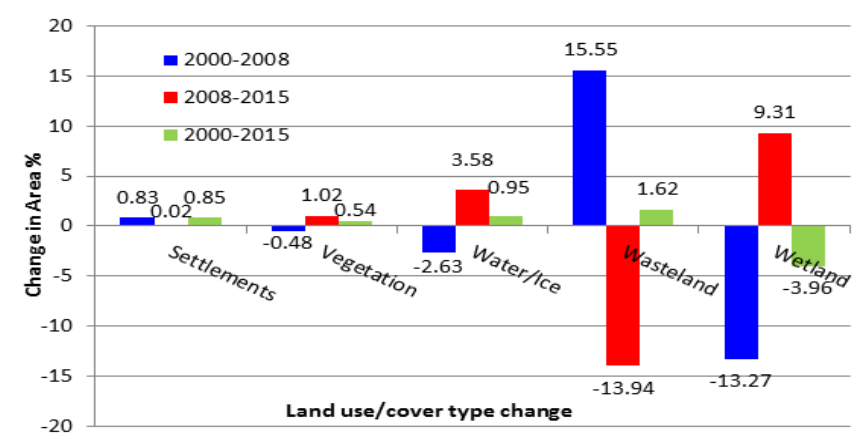

Fig. 5. Positive and negative land use/cover change in percent for 2000-2008, 2008-2015 and 2000-2015 in the study area.

Figure 5 shows both positive and negative land use/cove changes in the study area. Since last 15 years only wetland area has been decrease from $23011 \mathrm{~km}^{2}$ in 2000 to $20059 \mathrm{~km}^{2}$ in 2015 which accounts for $3.96 \%$ of the total study area (table 4). In the same time other class's settlements, vegetation, water/ice and Wasteland increase 
$0.85 \%, 0.54 \%, 0.95 \%$ and $1.62 \%$ respectively. In first half from 2000 to 2008 , the major change was in Wasteland and wetland. Wasteland was increase $15.55 \%$ $\left(11605 \mathrm{~km}^{2}\right)$ and wetland was decrease $13.27 \%\left(9900 \mathrm{~km}^{2}\right)$ of the total study area. From 2000 to 2008 total settlement area was increase from 453.59 to $1069.77 \mathrm{~km}^{2}$, which is $0.83 \%$ of the whole area. Water and vegetation area was reduced approximately $0.48 \%$ and $2.63 \%$ from 2000 to 2008 respectively. From 2008 to 2015 only Wasteland was reduced around $13.94 \%\left(10398.41 \mathrm{~km}^{2}\right)$ and other classes settlement, vegetation, water/ice, wetland were increased $0.02 \%\left(15.33 \mathrm{~km}^{2}\right), 1.02 \%(761.15$ $\left.\mathrm{km}^{2}\right), 3.58 \%\left(2673 \mathrm{~km}^{2}\right)$ and $9.31 \%\left(6948 \mathrm{~km}^{2}\right)$ respectively (table 4).

Table 4. Area and amount of change in different land use/cover categories in the study area during 2000 to 2015 .

\begin{tabular}{|c|c|c|c|c|c|c|c|c|c|c|c|c|}
\hline \multicolumn{3}{|c|}{2000} & \multicolumn{2}{|c|}{2008} & \multicolumn{2}{|c|}{2015} & \multicolumn{2}{|c|}{$2000-2008$} & \multicolumn{2}{|c|}{$2008-2015$} & \multicolumn{2}{|c|}{$2000-2015$} \\
\hline Class & Area & $\%$ & Area & $\%$ & Area & $\%$ & Diff. & $\%$ & Diff. & $\%$ & Diff. & $\%$ \\
\hline stivitivits & 453,59 & 0,61 & 1069,77 & 1,43 & 1085,10 & 1,45 & 616,18 & & 15,33 & 0,02 & 631,51 & 0,85 \\
\hline & 34558,78 & 46,32 & 34198,86 & 45,84 & 34960,01 & 46,86 & $-395,92$ & & 761,15 & 1,02 & 401,23 & 0,54 \\
\hline Water//ce & 15571,56 & 20,87 & 13610,66 & 18,24 & 16283,68 & 21,82 & -1960,90 & $-2,63$ & 2673,02 & 3,58 & 712,12 & 0,95 \\
\hline Whtthon & 1015,66 & 1,36 & 12620,89 & 16,92 & 2222,48 & 2,98 & 11605,23 & 15,55 & $-10398,41$ & $-13,94$ & 1206,82 & 1,62 \\
\hline Wetland & 23011,36 & 30,84 & 13110,77 & 17,57 & 20059,68 & 26,89 & $-9900,59$ & $-13,27$ & 6948,91 & 9,31 & $-2951,68$ & $-3,96$ \\
\hline Total & 74610,95 & & 74610,95 & & 74610,95 & & & & & & & \\
\hline
\end{tabular}

From 2000 to 2008 the main land encroachment was $9933.96 \mathrm{~km}^{2}$ area was converted from wetland to vegetation (table 5). In the same time $0.05 \%\left(39.34 \mathrm{~km}^{2}\right)$ settlement, $32.18 \%\left(24011.30 \mathrm{~km}^{2}\right)$ vegetation, $17.34 \%\left(12938.81 \mathrm{~km}^{2}\right)$ water/ice, $0.99 \%(740.83$ $\left.\mathrm{km}^{2}\right)$ Wasteland and $11.46 \%\left(8552.28 \mathrm{~km}^{2}\right)$ wetland of the total area was stable. Approximately $10.11 \%\left(7541.11 \mathrm{~km}^{2}\right)$ Wasteland was convert in vegetation from 2008 to 2015 (table 5). In this time period from 2008 to 2015, other classes settlements $0.03 \%\left(21.31 \mathrm{~km}^{2}\right)$, vegetation $34.18 \%\left(25947.25 \mathrm{~km}^{2}\right)$, water/ice $17.53 \%(13077.70$ $\mathrm{km}^{2}$ ), Wasteland $1.42 \%(1060.34)$ and wetland $11.29 \%\left(8426.08 \mathrm{~km}^{2}\right)$ was stable (table 5).

\section{Vulnerability analysis}

Natural and environmental vulnerability maps are shown relationship in between landscape and vulnerability and able to tackle answers such as comparing of different types of vulnerability zones in the study area and their causes.

Natural vulnerability map show that maximum area in safe zone as $38.61 \%$ area in sensible vulnerability and $29.84 \%$ area in moderate vulnerability zone, which represent that around $60 \%$ area of the total study area is safe zone. Around $14.54 \%$ area goes in high vulnerability which is really need proper management otherwise it will increase and harmful. The low vulnerability area is only $16.68 \%$ of the total study area, which is present in sea, river and water body area. Only $0.33 \%$ area has been under extreme vulnerability, which is very less and close to water bodies. High vulnerability area is close to costal line and near to river basin and in wetlands. High 
vulnerability is due to instability and extreme climate conditions. Maximum vegetation area and close to river basin area under moderate vulnerability zone. All Wasteland, some part of wetland and vegetation is under sensible and low vulnerability area, which represent maximum safe area in the study area. It's low vulnerability area due to less socioeconomic activities and high density of vegetation (Fig. 6).

Table 5. Land use/cover change matrix showing land encroachment of the study area.

\begin{tabular}{|l|r|r|r|r|r|r|}
\hline 2000-2008 & SETTLEMENT & VEGETATION & WATER_ICE & WESTLAND & WETLAND & Total \\
\hline Settlements & 39,34 & 32,78 & 75,39 & 22,95 & 299,94 & 470,39 \\
\hline Vegetation & 345,83 & 24011,30 & 24,58 & 8753,88 & 1575,08 & 34710,66 \\
\hline Water/Ice & 9,83 & 26,22 & 12938,81 & 11,47 & 2591,24 & 15577,58 \\
\hline Wasteland & 18,03 & 127,84 & 44,25 & 740,83 & 157,34 & 1088,29 \\
\hline Wetland & 655,60 & 9933,96 & 503,17 & 3119,01 & 8552,28 & 22764,02 \\
\hline Total & 1068,63 & 34132,10 & 13586,21 & 12648,13 & 13175,88 & 74610,95 \\
\hline & & & & & & \\
\hline 2008-2015 & SETTLEMENT & VEGETATION & WATER_ICE & WESTLAND & WETLAND & Total \\
\hline Settlements & 21,31 & 381,89 & 8,20 & 21,31 & 635,94 & 1068,64 \\
\hline Vegetation & 27,86 & 25947,25 & 6,56 & 1106,34 & 7062,52 & 34150,53 \\
\hline Water/Ice & 1,64 & 45,89 & 13077,70 & 1,64 & 427,78 & 13554,66 \\
\hline Wasteland & 514,75 & 7541,11 & 43,94 & 1060,34 & 3505,85 & 12666,00 \\
\hline Wetland & 526,22 & 1014,55 & 3123,96 & 80,31 & 8426,08 & 13171,13 \\
\hline Total & 1091,78 & 34930,70 & 16260,36 & 2269,94 & 20058,17 & 74610,95 \\
\hline
\end{tabular}

Environmental vulnerability map is more sensitive than natural vulnerability. In environmental vulnerability around $50 \%$ area under moderate vulnerability zone but high and extreme vulnerability is higher than natural vulnerability. Here $15.73 \%$ area under high vulnerability and $14.54 \%$ under extreme vulnerability. Sensible vulnerability is only $3.75 \%$ and low vulnerability is $16.68 \%$. Low vulnerability is present in sea, river and water bodies and sensible vulnerability present in Wasteland and some patches in vegetation. Maximum study area has been under moderate vulnerability, which is present in vegetation and close to wetland and costal line. High vulnerability is present in close to coastline and along to river and its channels. In the study area there is extreme vulnerability having three big patches in wetland, close to costal line and river (fig. 6).

As study area is in northern part of the Asia with Artic sea so maximum time of the year it's cover with ice, with harsh climatic condition (Bai et. al 2012). In winter only airways are the only way of approaching this area but in winter Indigirka River also provide transportation facility. That's why only one town and two small villages present in the study area with less than 3000 inhabitance due to punitive climatic conditions. Here land use/cover classes and there convergent or encroachment induced by extreme cold and tough climatic condition in the study area. In extreme cold condition maximum areas convert in Wasteland, where land has been un useful or unfertile. But in summer session ice has been melt and maximum land convert into wetland and vegetation area. 


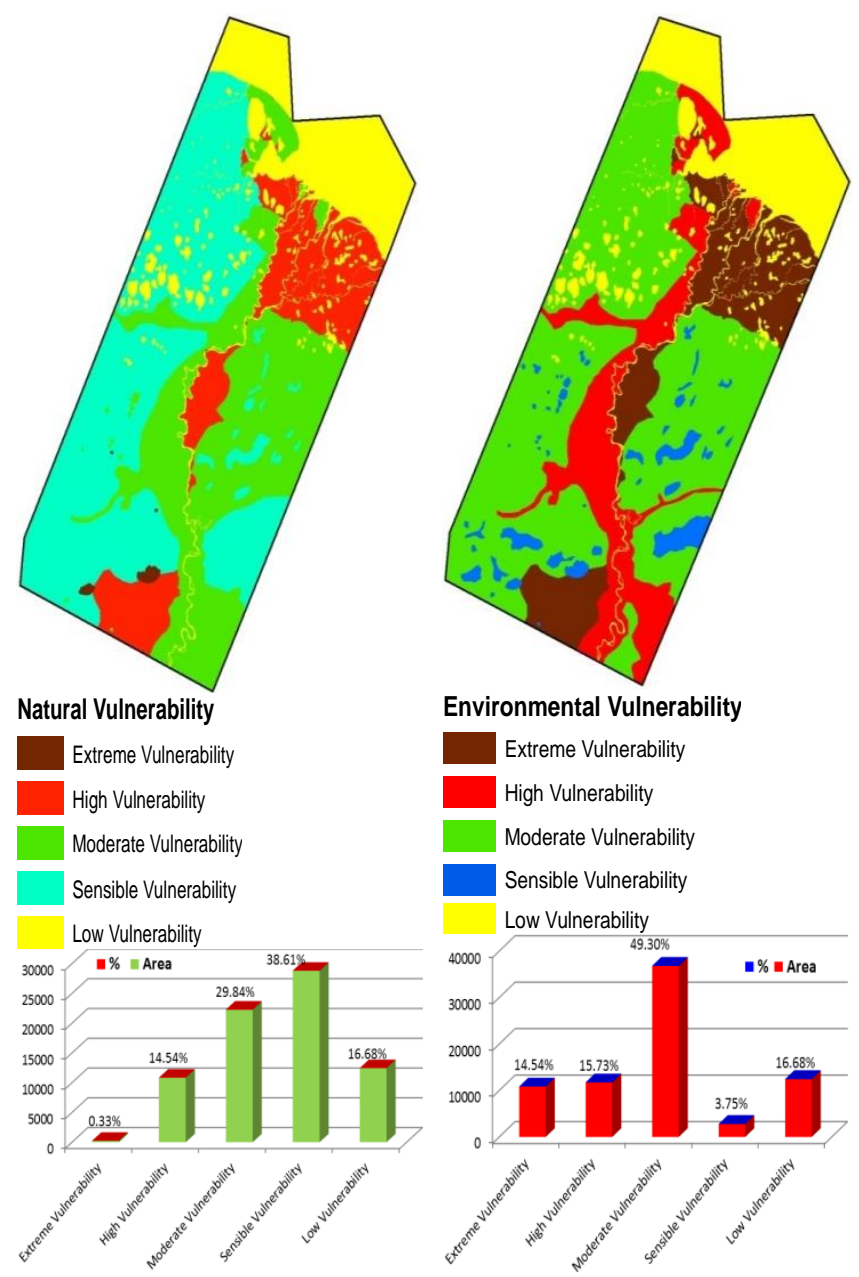

Fig. 6. Natural and environmental vulnerability map.

\section{Conclusion}

Present study shows the importance of land use/cover change detection and vulnerability assessment for resource management and planning and their sustainable development. The results of this research work is helpful for proper utilization of land, there accurate strategical development and conversion in specific timeframe. Here remote sensing and GIS data provide extensive opportunity for this type of land use/cover change study, which is not possible with conventional methods in inaccessible area. Results shows that: 
- In first half (2000-2008) Wasteland area was increased from 1015 to $12620 \mathrm{~km}^{2}$ by $15 \%$ and wetland reduced by $13 \%$.

- In second half from 2008 to 2015 Wasteland shrink more than $13 \%$ and wetland augmented around $9 \%$ but in the same time period other classes have minor variation.

- Natural and environmental vulnerability can be modelled by using remote sensing and GIS.

- There is very less extreme natural vulnerability.

- Maximum area has been under moderate vulnerability zone for both type of vulnerability.

- Natural and environmental vulnerability is influenced by harsh climate conditions, vegetation cover, erosion, degradation of land and socio-economic activities.

Land use/cover change and vulnerability scenarios are useful for exploring uncertainties in vulnerability assessment on a regional basis, e.g. some regions show equal vulnerability to all scenarios, whilst other regions show different responses. This is an indicator for where we can be more or less uncertain about the future. Furthermore, it helps in indicating how society and policy can have an important role to play in future development pathways. The mapping, monitoring and modelling of land use/cover in such a vast territory as Siberia could also contribute to the study of global environmental change.

\section{Acknowledgements}

This data work is financially supported by the Russian Scientific Foundation (RSF), grant no. 14-31-00014 "Establishment of a Laboratory of Advanced Technology for Earth Remote Sensing”.

\section{References}

1. Kok M, Lüdeke M, Lucas P, Sterzel T, Walther C, Janssen P, Sietz D, Soysa ID. A new method for analysing socio-ecological patterns of vulnerability. Regional Environmental Change, 2016; 16(1): 229-243.

2. Boori MS, Choudhary K, Kupriyanov AV, Kovelskiy V. Four decades urban growth and land use change in Samara Russia through remote sensing and GIS techniques. SPIE Remote Sensing and Image Formation, 2015; 9817: 01-07. DOI:10.1117/12.2227992.

3. Tricart E. Revista Brasileira de Geomorfologia Ano 8, nº 2, 2007: 1977.

4. Chen L, Michishita R, Xu B. Abrupt spatiotemporal land and water changes and their potential drivers in Poyang Lake, 2000-2012. ISPRS Journal of Photogrammetry and Remote Sensing, 2014; 98: 85-93.

5. Boori MS, Choudhary K, Kupriyanov AV, Kovelskiy V. Urbanization data of Samara City, Russia. Data in Brief, 2016; 6: 885-889. DOI:10.1016/j.dib.2016.01.056.

6. Aretano R, Semeraro T, Petrosillo I, De Marco AD, Pasimeni MR, Zurlini G. Mapping ecological vulnerability to fire for effective conservation management of natural protected areas. Ecological Modelling, 2015; 295: 163-175. 
7. Boori MS, Ferraro RR. Global Land Cover classification based on microwave polarization and gradient ratio (MPGR). Geo-informatics for Intelligent Transportation, Springer International Publishing Switzerland, 2015; 71: 17-37. DOI:10.1007/978-3-319-11463-7-2.

8. Romero AF, Abessa DMS, Fontes RFC, Silva HG. Integrated assessment for establishing an oil environmental vulnerability map: Case study for the Santos Basin region, Brazil. Marine Pollution Bulletin, 2013; 74(1): 156-164.

9. Yabuki H, Park H, Kawamoto H, Suzuki R, Razuvaev VN, Bulygina ON, Ohata T. Baseline Meteorological Data in Siberia (BMDS). Version 5.0, RIGC, JAMSTEC, Yokosuka, Japan, Distributed by CrDAP, Digital Media, 2011.

10. Boori MS, Choudhary K, Kupriyanov AV, Kovelskiy V. Satellite data for Singapore, Manila and Kuala Lumpur city growth analysis. Data in Brief, 2016; 7: 885-889. DOI:10.1016/j.dib.2016.04.028.

11. Barbosa CCF. Álgebra de mapas e suas aplicações em Sensoriamento Remoto e Geoprocessamento. 111 f. Dissertação (Mestrado em Sensoriamento Remoto) - Instituto Nacional de Pesquisas EspaciaisINPE, São José dos Campos, 1997.

12. Padgett J, Tapia C. Sustainability of Natural Hazard Risk Mitigation: Life Cycle Analysis of Environmental Indicators for Bridge Infrastructure. J. Infrastruct. Syst., 2013; 19(4): 395-408.

13. Xavierdasilva J. et al. Índices de geodiversidade: aplicações de SGI em estudos de biodiversidade. In: Garay I, Dias BFS. (Orgs.). Conservação da biodiversidade em ecossistemas tropicais: avanços conceituais e revisão novas metodologias de avaliação e monitoramento. Rio de Janeiro, Vozes, 2001: 299-316.

14. Grigio AM, Castro AFDe, Souto MVS, Amaro VE, Vital H, Diodato MA. Use of remote sensing and geographical information system in the determination of the natural and environmental vulnerability of the Guamare municipal district. Rio Grande do Norte - northeast of Brazil. Journal of Coastal Research, SI 39, pg - pg. Itajaí, SC - Brazil. 